МОТИВАЦІЯ СТУДЕНТІВ ЗВО НЕМОВНИХ СПЕЦІАЛЬНОСТЕЙ ДО ВИВЧЕННЯ НОВОГО ЛЕКСИКО-ГРАМАТИЧНОГО МАТЕРІАЛУ ЗА УМОВИ КОЛЕКТИВНОЇ ПРАЦІ НА ПРАКТИЧНИХ ЗАНЯТТЯХ

\title{
THE MOTIVATION OF STUDENTS AT NON-LINGUISTIC UNIVERSITIES FOR LEARNING NEW LEXICAL AND GRAMMATICAL MATERIAL SHOULD BE IMPROVED BY STUDENTS' ACTIVITY DURING PRACTICAL LESSONS
}

\begin{abstract}
y cmammi розглянута проблема срормування мотивації для підвищення зацікавленості студентів ЗВО немовних спеціальностей до вивчення іноземної мови. Проаналізовано розподіл мотивації на зовнішню та внутрішню. Також розглянуто проблеми відсутності мотивації в студентів до навчання. Наводяться приклади й даються поради, як покращити навчальнопізнавальну діяльність студентів. Особливості процесу оволодіння новим граматичним і лексичним матеріалом наведено в таблиці переваг і недоліків використання онлайн перекладача під час практичних занять для перекладу текстів економічної спрямованості. Багато студентів нелінгвістичних спеціальностей, рівень володіння англійською мовою яких варіюється від початкового рівня (A1) до рівня нижче за середній (А2), користувалися онлайн перекладачем для перекладу всього тексту загалом, не перекладаючи окремо слова та речення. Отже, як результат, їхній словниковий запас залишався практично незмінним. Студенти повинні оволодіти методи кою користування онлайн перекладачем для розширення знання іноземною мови. Вони мають зрозуміти та сприйняти необхідність не тільки перекладати нове слово, а й дізнатися його значення та правильно використовувати че слово в реченнях. Мета cmammi - надати інорормацію про наявність справжньої проблеми мотивації вивчення іноземної мови та виявити цінності для стимулювання студентів до ефективних зусиль у здобутті освіти. Актуальність матеріалу статті зумовлена суспільною потребою у володінні іноземними мовами та усвідомленням важливої ролі зацікавленості студентів у прочесі навчання. Ефрективність навчання частково залежить від глибини внутрішніх потреб та отримання задоволення від успіхів у навчанні. Важливо розуміти, що рівень успішності в отриманні нових знань залежить від сили (глибинного внутрішнього) мотиву. Він пов'язаний зі зростанням інтересу до навчання й удосконалення знань студентів. Цей мотив $\epsilon$ джерелом дій, якими повинен керувати викладач.
\end{abstract}

2019-19-1-11

\section{Васильєва К.В.}

викладач кафедри іноземних мов

Одеського національного економічного університету
Ключові слова: мотивачія, іноземна мова внутрішня мотивація, зовнішня мотивація, викладач, студент.

This article outlines the problem of formation of the motivation among students of non-linguistic specialities to increase the interest of learning a foreign language. The division of motivation into external and internal was analysed. The problems of lack of students' motivation to learning were also considered. Examples and tips of the improvement of educational and cognitive activities of students were provided. The features of the process of understanding new grammar and lexical material are shown in the table of advantages and disadvantages of using online translator during practical lessons. Many students of non-linguistic specialties whose level of English is varied from A1 to A2 used to translate the whole text without separating words and sentences. So as a result, their vocabulary is almost constantly very poor. Students got to master the correctness of using online translator for increasing their knowledge of a foreign language. It is very useful not only to translate the new word but to understand its meaning and to use it correctly. The purpose of the article is to give the reader some information on the real problem in motivating of a foreign language learning. The other problems are to discover values and to stimulate the students to effective effort in getting education. The relevance of material presented in the article is caused by social need to know foreign languages and awareness of its importance in the process of teaching and learning for students. The effectiveness of learning partly depends upon the strength of the needs and upon the satisfaction the learning brings. It is important to understand that the rate of learning depends upon the strength of the motive. Motivation is one of the main concepts of the learning process. The level of motivation sets not only in motion the activity which results in learning, but also sustains and directs it. It is concerned with the arousal of interest in learning and improving students 'knowledge of the foreign languages. Key words: motivation, foreign language, internal motivation, external motivation, teacher, student.
Постановка проблеми в загальному вигляді. Питання мотивації студентів немовних спеціальностей під час навчання іноземної мови $€$ основним, оскільки в цієї категорії студентів переважно відсутня мотивація до вивчення англійської мови. Однією з умов успішного навчання $є$ інтерес самих студентів до вивчення іноземної мови, бажання приділяти йому час і докладати додаткові зусилля для оволодіння мовою.

Аналіз останніх досліджень і публікацій. Проблема фрормування мотивації балансує між такими двома аспектами, як навчання й вихо- вання. Треба розуміти, що увага викладачів повинна бути спрямована не тільки на здійснення студентом навчання, а й на те, що мотивує студента до саморозвитку та самовдосконалення в процесі навчально-пізнавальної діяльності.

Виявлено критерії та показники, які дають змогу виділити чотири рівні сфрормованості мотивації вивчення іноземної мови в студентів вищих нелінгвістичних закладів освіти:

- рівень відсутності мотивації (негативна внутрішня мотивація учіння, закладена в навчальну діяльність суб'єктів навчання); 
- низький рівень (негативна зовнішня мотивація учіння, яка знаходиться поза навчальною діяльністю суб'єктів навчання);

- середній рівень (позитивна зовнішня мотивація, яка безпосередньо знаходиться поза навчальною діяльністю суб'єктів навчання);

- високий рівень (позитивна внутрішня мотивація, закладена в навчальну діяльність суб'єктів навчання) [2, с. 10]

Формування мотивації - це виховний процес, створення системи цінностей і пріоритетів, соціально прийнятних в українському суспільстві, що означає взаємозв'язок між усвідомленнями та мотивами, які заохочують студентів до навчання. Мотиви, що спонукають до діяльності та навчання, пов'язані із задоволенням потреб. Розрізняючи мотиви, студент сприймає необхідність навчання й оволодіння новим матеріалом, але не обов'язково це спонукає його до навчальної діяльності.

Сучасний викладач ЗВО має завдання задіяти в навчанні такі методи, які пробуджуватимуть і підтримуватимуть у студентів інтерес до пізнання нового. За цих умов вагомого значення набуває мотивація як важливий компонент освіти. Від мотивації студента залежить не тільки його успішність у навчанні у ЗВО, а також бажання отримувати додаткові знання та самовдосконалюватися протягом усього життя. А це є дуже важливо, оскільки, згідно із сучасними дослідженнями, результати діяльності людини тільки на 20\% залежать від інтелекту, а на 70-80\% - від мотивації.

Мотивацію варто розглядати не як короткочасний фрактор діяльності, який можна відкинути після досягнення мети. Ідеться про те, щоб почуття обов'язку було стабільним і закріплювалося в характері людини як постійне прагнення до діяльності, щоб воно стало рисою людини та впливало на хід її життєдіяльності й тоді, коли самі стимулювальні фрактори перестають діяти [3, с. 85].

Мета статті - надати інформацію про наявність справжньої проблеми мотивації вивчення іноземної мови та виявити цінності для стимулювання студентів до ефективних зусиль у здобутті освіти.

Виклад основного матеріалу. Мотивація - це сукупність таких фракторів, як інтереси, потреби, прагнення, емоції, переконання, ідеали, установки, що спонукають студента до навчальної діяльності та викликають у нього прагнення до саморозвитку. Правильно поставлена мотивація спонукає студента діяти з максимальною енергією в різних навчальних і повсякденних ситуаціях.

3 метою поліпшення процесу фрормування мотивації викладач має сприяти створенню на заняттях такого навчального середовища, у якому 6 студенти відчували внутрішню потребу навчатися та самовдосконалюватися. Цього можна досягти за умови, коли студент самостійно обирає собі мету й докладає зусилля, аби ії досягти.
Необхідними умовами мотивації студента вважаються:

- допитливість студента;

- прагнення задовольнити допитливість;

- бажання самовдосконалюватися;

- наполегливість щодо досягнення поставленої мети.

Відомі три види мотивації студентів до навчання - зовнішня, внутрішня, та глибинна внутрішня.

\section{Зовнішня мотивація}

Студент, мотивований зовні, бере участь у навчальному процесі мотивації заради визнання, отримання високих балів і похвали. Він $€$ мало зацікавленим у саморозвитку та працює на короткотривалу перспективу. У цьому разі студент насамперед зацікавлений у такому:

- заслужити похвалу;

- не отримати низький бал.

Водночас студенту необхідно працювати на довготривалу перспективу:

- розвиток;

- удосконалення знань.

Як наслідок, такі студенти вважають причиною своїх невдач і неуспішності зовнішні сили. Вони сприймають свою невдачу як постійну. Такі студенти потребують заохочення, інакше в них виникає переконаність у відсутності в них здібностей до вивчення іноземної мови.

\section{Внутрішня мотивація}

Студенти самі визначають собі цілі, яких прагнуть досягти у вивчанні іноземної мови. Так у студента розвивається глибинний інтерес до навчання та саморозвитку. Студент уважає кращою винагородою почуття власної гідності, підвищення самооцінки, задоволення від того, що він рухається в правильному напрямі для досягнення мети, яку сам собі визначив. Такий студент не звертає особливої уваги на набрані бали, а досягає успіхів у навчанні завдяки внутрішньому інтересу здобути нові знання, прагненню досягнути поставленої мети тощо. Він добре розуміє, що будь-яка невдача пояснюється тим, що він доклав недостатньо зусиль для опрацьовування нового матеріалу та не сорормував належну базу знань у відповідній предметній області. Студент бере на себе відповідальність за власні невдачі на себе й не втрачає зацікавленості в навчанні. У цьому разі для студента $€$ важливим:

- досягнення поставленої мети під час вивчення іноземної мови;

- емоції, які викликає процес навчання;

- уміння вчитися й застосовувати отримані знання на практиці.

\section{Внутрішня глибинна мотивація}

Внутрішня глибинна мотивація складається з мотивації та мотивів. Вона залежить від бажання самого студента до навчання, пізнавання нового 
й постійного саморозвитку. Мотивація - це ті цілі, які людина собі ставить, а мотиви - те, що вона насправді хоче робити, і те, що спонукає ії до діяльності. 3 часом мотивація може зменшуватися, але мотиви існують завжди.

Отже, у системі навчальних мотивів студентів наявні як внутрішні мотиви навчальної діяльності, так і мотиви, які є зовнішніми щодо навчальної діяльності. Одним із основних завдань вишівського викладання $є$ підвищення в структурі мотивів студента питомої ваги внутрішньої мотивації, змістовно близької до навчальної діяльності [1, с. 319].

Для викладача є важливим створити умови для появи в студентів як зовнішньої, так і внутрішньої мотивації. Викладач має добирати такий навчальний матеріал, який би викликав у студентів інтерес до пізнання нового. Викладач має заохочувати та мотивувати студентів до діяльності й вивчення нового лексично-граматичного матеріалу, використовуючи такі види завдань, як рольові ігри, створення презентацій, робота в малих групах тощо.

Досвід викладання іноземної мови в немовних фракультетах 3 ВО доводить, що в групі завжди присутні студенти з різним рівнем базової підготовки. Разом із цим студенти мають різні індивідуальні особливості, які не завжди вдається виявити одразу.

На початку першого навчального семестру 2019 року студентам першого курсу всіх фракультетів було запропоновано пройти вхідний тест на виявлення рівня володіння іноземною мовою, що складався зі 100 питань різної складності. Після тестування студенти були поділені на групи з низьким, середнім і високим рівнем володіння іноземною мовою.

Я викладаю англійську мову профресійного спілкування в групах першого курсу обліково-економічного фракультету з низьким рівнем володіння іноземною мовою. Для цих студентів $є$ складним розуміння та опрацьовування звичайного тексту, а тексти економічної спрямованості виявляються для них ще складнішими.

3 метою покращення навчально-пізнавальної діяльності нами запроваджена колективна робота студентів на практичному занятті для опрацювання вправ до економічного тексту.

На парі були присутні 20 студентів (загалом у групі 23 студенти).

Одним із завдань практичного заняття, яке виконували студенти, була вправа, в якій запропоновано 20 словосполучень економічного характеру й надано 20 речень, у яких необхідно використати ці словосполучення.

Метою завдання було:

- залучення всіх присутніх на практичному занятті студентів до участі в активній роботі;

- засвоєння нового лексичного матеріалу;

- опрацьовування поточного граматичного матеріалу;
- оволодіння технікою самостійного перекладу тексту економічної тематики для студентів немовних фракультетів.

У сучасних студентів $є$ можливість користуватися онлайн перекладачем для перекладу нових слів, які не входять до нової активної лексики, $€$ незнайомими для студентів із низьким рівнем володіння іноземної мови. Але більшість студентів, можливо, задля економії часу намагається перекладати повністю весь текст, а не лише окремі слова, що негативно впливає на сприйняття й засвоєння нового лексично-граматичного матеріалу. Далі подана таблиця переваг і недоліків використання онлайн перекладача для перекладу не окремих слів і словосполучень, а всього тексту разом.

Таблиця 1

Переваги й недоліки для студентів, які перекладають тексти за допомогою онлайн перекладачів

\begin{tabular}{|l|l|}
\hline \multicolumn{1}{|c|}{ Переваги } & \multicolumn{1}{|c|}{ Недоліки } \\
\hline Економія часу & $\begin{array}{l}\text { Відсутність навичок засво- } \\
\text { єння та опрацьовування нової } \\
\text { лексики }\end{array}$ \\
\hline $\begin{array}{l}\text { Готовий переклад, } \\
\text { який можна зачитати } \\
\text { на парі }\end{array}$ & $\begin{array}{l}\text { Невміння самостійно пере- } \\
\text { кладати тексти, фрормулюючи } \\
\text { окремі слова в зрозумілі } \\
\text { речення }\end{array}$ \\
\hline Виконання завдання & $\begin{array}{l}\text { Невміння працювати зі слов- } \\
\text { ником }\end{array}$ \\
\hline
\end{tabular}

На практичному занятті нами запропоновано таке.

Перше завдання, яке необхідно було виконати, - перекласти словосполучення економічного характеру з англійської мови українською за допомогою онлайн словника. Кожному студенту треба було перекласти по одному слову чи словосполученню з 20 наданих у завданні.

Наступне завдання мало такий вигляд:

20 речень розподілялися так, що кожна пара студентів (було 10 пар студентів) мала перекласти по два речення та виписати нові чи незнайомі для них слова, що пов'язано з тим, що для студентів із груп із низьким рівнем володіння іноземною мовою більшість слів $€$ новими.

Заключне завдання полягало в тому, щоб ознайомити всіх присутніх студентів 3 новою лексикою за допомогою колективної праці самих студентів. Один зі студентів писав на дошці слова, які вони перекладали. Інші студенти записували їх у конспекти. I так робили всі десять пар присутніх на занятті студентів. Кожен зі студентів по черзі демонстрував на дошці нові слова й ті слова, які були незнайомі для нього (чи неї). Десять пар студентів переклали по два речення. Кожний студент працював над вправою. Усі дізналися нові слова й записали їх у конспекти. 
За результатом виконання завдання, студенти насамперед були задоволені, що завдання було їм зрозумілим і вони виявилися здатними його виконати, отримавши навички працювати в команді. Не можу не зауважити, що вони не менше раділи, що хтось виконав частину роботи, а не кожен студент перекладав усе завдання самостійно. Після успішного завершення їм було приємно усвідомлювати, що кожен із них брав участь у колективному опрацюванні матеріалу. Зрозумівши зміст усіх речень, студенти обговорили можливі варіанти перекладу.

Мета запропонованого завдання на прикладі виконання однієї лексично-граматичної вправи:

- усвідомлення необхідності правильно користуватися онлайн перекладачем;

- формування вміння виконувати завдання, працюючи в парі з іншим студентом;

- економія часу (той аспект, до якого звикли сучасні студенти);

- ознайомлення всіх присутніх на занятті студентів з новою лексикою економічного характеру;

- набуття студентами досвіду самостійної роботи для подальшого виконання домашнього й аудиторного завдання.

Висновки. Мету й значення мотивації повинні чітко усвідомлювати як викладач, так і самі студенти. Викладачі можуть бути ефективними в тому, щоб заохочувати студентів зосереджува- тися на навчанні замість ефективності виконання. Основна мета мотивації - стимулювати навчальну діяльність і сприяти їй, заохочувати студентів до вивчення іноземної мови та сприяти підвищенню ефективності процесу навчання.

\section{БІБЛІОГРАФІЧНИЙ СПИСОК:}

1. Тригуб І.П. Мотивація студентів як один із основних фракторів успішної профресійної підготовки. Наукові записки Національного університету «Осmрозька академія» : збірник наукових праць. Київ, 2014. Вип. 48. С. 318-321.

2. Арістова Н.О. Формування мотивації вивчення іноземної мови у студентів вищих нелінгвістичних навчальних закладів : авторефр. дис. ... канд. пед. наук : 13.00.04 «Теорія і методика професійної освіти». Київ, 2008.

3. Козак М.В. Роль мотивації та шляхи її підвищення при вивченні іноземних мов. Науковий вісник Ужгородського національного університету. Серія «Педагогіка, соціальна робота». 2015. Вип. 35. С. 84-87.

4. URL: http://www.yourarticlelibrary.com/motivation/ importance-of-motivation-in-education-499-w0rds/6062.

5. URL: http://www.yourarticlelibrary.com/learning/ importance-of-emotions-in-teaching-and-learning-702words/6040.

6. URL: https://gointothestory.blcklst.com/readerquestion-how-would-you-define-inner-motivation-andouter-motivation-4df152452f5b. 